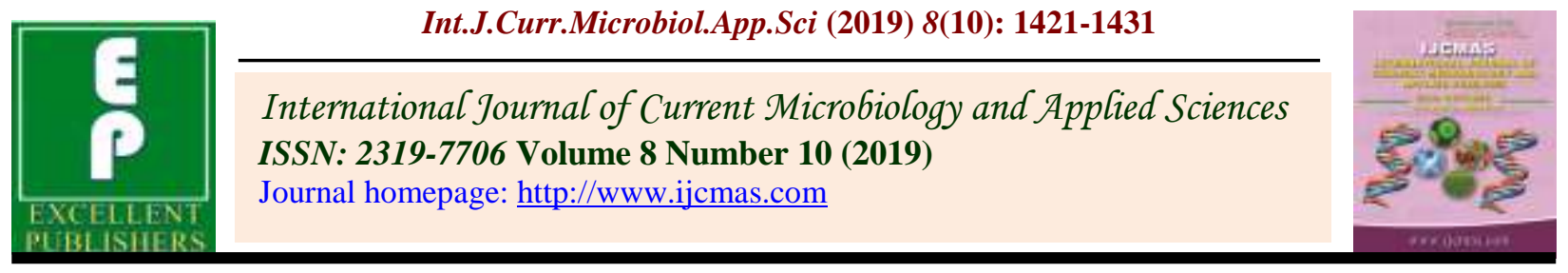

Original Research Article

https://doi.org/10.20546/ijcmas.2019.810.167

\title{
Groundwater Arsenic Contamination and its Distribution in Bhojpur District, Bihar, India
}

\author{
Manish Kumar $^{1 *}$, V. K. Chandola ${ }^{1}$ and Sumant Kumar ${ }^{2}$ \\ ${ }^{1}$ Department of Farm Engineering, Institute of Agricultural sciences Banaras Hindu \\ University Varanasi, Uttar Pradesh-221005, India \\ ${ }^{2}$ National Institute of Hydrology, Roorkee, Uttarakhand-247667, India
}

*Corresponding author

\section{A B S T R A C T}

\section{Keywords}

Arsenic, Iron,

Drinking water and

contaminations

Article Info

Accepted:

12 September 2019

Available Online:

10 October 2019
Ground water is the major source of drinking water in both rural and urban areas which may be contaminated by various means, Arsenic is one of them. Forty five hand-pump and river samples (containing 250ml each) from different blocks of Bhojpur district, Bihar were collected in sterile containers and analyzed. The values were found as $\mathrm{pH}(6.5-8.5), \mathrm{EC}(277-1415 \mu \mathrm{S} / \mathrm{cm})$, TDS $(237-1034 \mathrm{mg} / \mathrm{L})$, As (0-785 ppb), Al (35.1-117 ppb), Cd (0-83 ppb), Cr (0-5 ppb), Cu (0-10 ppb), Ni (0-11 ppb), Pb (0-24 ppb), Mn (2.1-1303 ppb), Zn (110-2190 ppb) and Fe (0.06$14.39 \mathrm{mg} / \mathrm{L}$ ). The results compared with the drinking water standard prescribed by Bureau of Indian Standard (BIS) and it was observed that all the water quality parameters were within permissible limit of drinking water except As and Fe for most of the samples. Almost $40 \%$ of samples were within the acceptable limit of As $(10 \mathrm{ppb})$ prescribed by BIS, 2012. Approximately $\sim 60 \%$ of water samples were enriched with As concentrations $>10 \mu \mathrm{g} / \mathrm{L}$, which ranged from below detectable limit (BDL) to $785 \mu \mathrm{g} / \mathrm{L}$ (average $162 \mu \mathrm{g} / \mathrm{L}$ ). In case of Fe as $68.88 \%$ which exceeded the acceptable limit of $0.30 \mathrm{ppm}$ as prescribed by BIS, 2012. High concentration of iron and arsenic may be attributed to the dissolution of pyrite bearing minerals from the geological strata.

\section{Introduction}

Groundwater contains wide variety of dissolved inorganic chemical constituents in various concentrations, resulting from chemical and biochemical interactions between water and the geologic materials. Some regions of various states of India are contaminated by Salinity, Arsenic, Fluoride, Iron and Nitrate etc. Higher concentration of arsenic in ground water is generally reported to be geogenic. Arsenic in ground water beyond the BIS acceptable and permissible limit of 10 and $50 \mathrm{ppb}$ respectively has been reported from many states namely West Bengal, Bihar, Uttar Pradesh, Assam, 
Manipur, Jharkhand, Punjab, Haryana, Chhattisgarh and Karnataka etc (CGWB, 2015). Mostly the Indo Ganetic alluvium and the Brahmaputra alluvium have higher concentration of arsenic in localized pockets. Fluoride contamination (more than $1.5 \mathrm{mg} / \mathrm{l}$ ) in ground water is widely prevalent in different parts of India, mostly in the states of Telangana, Andhra Pradesh, Rajasthan, Maharashtra, Madhya Pradesh, West Bengal, Bihar, Odisha, Punjab, Haryana, Tamil Nadu, Uttar Pradesh, Karnataka and Gujarat (CGWB, 2015). Some parts of Chhattisgarh, Delhi and Kerala are also affected by Fluoride contamination. Salinity in ground water is found mainly in western, north western and southern parts of India. Salinity has been observed in all major aquifer systems. Inland salinity caused by high sulphate in ground water has also been reported from some parts of the country. High levels of iron in ground water (more than $0.3 \mathrm{mg} / \mathrm{l}$ ) have been reported from many states (CGWB 2015). Pollution due to human and animal wastes and fertilizer application has resulted in higher levels of potassium and nitrate in ground water in some parts of the country. Ground water pollution due to indiscriminate disposal of industrial effluents has been reported as localised contamination in major industrial zones.

\section{Arsenic in Groundwater}

Arsenic is a metalloid with symbol As an atomic number 33, atomic mass 74.92. Arsenic forms colorless, odorless, crystalline compounds $\mathrm{As}_{2} \mathrm{O}_{3}$ and $\mathrm{As}_{2} \mathrm{O}_{5}$, which are hygroscopic in nature and readily soluble in water to form acidic solutions. Arsenic is found in the natural environment in abundance in the Earth's crust and in small quantities in rock, soil, water and air. The most common oxidation states for arsenic are: -3 (arsenides: usually alloy-like intermetallic compounds), +3 (arsenites (As (III) and most organoarsenic compounds), and +5 (arsenates (As $(\mathrm{V})$ ): the most stable inorganic arsenic oxy-compounds. It can exist in organic and inorganic form. Inorganic arsenic is generally more toxic than organic arsenic. Inorganic arsenic occurs naturally in many types of rocks and it is generally found with sulphide ore arsenopyrite. Inorganic arsenic compounds known to be human carcinogens. Arsenic in elemental form is insoluble in water but it is soluble in oxidised form. Arsenic is a natural constituent in bedrock and soil. It usually occurs at low concentrations (average 1-2 $\mathrm{mg} / \mathrm{kg}$ ) in the Earth's crust (Behattacharya et al., 2002), but may be concentrated in certain rock types and especially in gold and sulphide-bearing ore deposits and occurrences. Pyrite $\left[\mathrm{FeS}_{2}\right.$; or arsenian pyrite $\left.\mathrm{Fe}(\mathrm{AsS})_{2}\right]$ and arsenopyrite [FeAsS] are typical sulphide minerals containing As. Arsenic is mobilized through a combination of natural processes such as weathering reactions, biological activity, and volcanic emissions as well as through a range of anthropogenic activities such as gold mining, nonferrous smelting, petroleum-refining, combustion of fossil fuel in power plants, and the use of arsenical pesticides and herbicides (Biswas et al., 2008; Smedley and Kinniburgh, 2002; Violante et al., 2006). Arsenic is immediately dangerous to life or health at $5.0 \mathrm{mg} / \mathrm{m}^{3}$. The human body does not readily absorb the element itself; hence, pure arsenic is much less dangerous than arsenite $\left(\mathrm{As}^{+3}\right)$ compounds such as arsenic trihydride or arsine $\left(\mathrm{AsH}_{3}\right)$ and arsenic trioxide $\left(\mathrm{As}_{2} \mathrm{O}_{3}\right)$, which are absorbed easily and are carcinogenic at high toxicity. Humans are exposed to arsenic, mainly inorganic arsenic and predominantly through contaminated drinking water, whereas inhalation and skin absorption are minor routes of exposure (Shi et al., 2004). Chronic arsenicism has affected more than 300 million people worldwide, approximately 85 million of whom reside in Bangladesh. The major arsenic-prone areas have been reported in large deltas and/or along major river basins 
across the world (Fendorf et al., 2010; Shankar et al., 2014). A number of such arsenic prone regions in the world with deltas and river basins include alluvial and deltaic aquifers in Bangladesh (Chakraborti et al., 2015; Smith et al., 2000a), the Paraiba do Sul delta in Brazil (Mirlean et al., 2014), the Ganges-Brahmaputra Plain in India (Das et al., 2009), the Red river basin and Mekong Delta in Vietnam (Nguyen et al., 2009) etc. The clinical symptoms of arsenic toxicity in human body include skin itching to sun rays, burning and watering of the eyes, weight loss, loss of appetite, weakness, fatigue, limited physical activities and working capacities, chronic respiratory problems, moderate to severe anaemia etc.

Heavy withdrawal of groundwater for fulfilling the needs of the increasing population in Bengal Basin resulted in increased arsenic level in the groundwater. Mobilization of arsenic in Bengal delta is further interfered by microbial activities and interactions. Arsenic naturally occurs in over 200 different mineral forms, of which around $60 \%$ are arsenates, $20 \%$ are sulfides and sulfosalts and the rest $20 \%$ are arsenides, arsenites, oxides, silicates and elemental arsenic (Bissen and Frimmel, 2003).

Major arsenic containing primary minerals are arsenopyrite (FeAsS), realgar $\left(\mathrm{As}_{4} \mathrm{~S}_{4}\right)$, and orpiment $\left(\mathrm{As}_{2} \mathrm{~S}_{3}\right)$. Realgar $\left(\mathrm{As}_{4} \mathrm{~S}_{4}\right)$ and orpiment $\left(\mathrm{As}_{2} \mathrm{~S}_{3}\right)$ are the two common reduced forms of arsenic whereas the oxidized form is the mineral arsenolite $\left(\mathrm{As}_{2} \mathrm{O}_{3}\right)$.

Exposure to sufficiently high concentrations of inorganic arsenic in natural environment has proved to be harmful to the organisms.

The main pathways of arsenic exposure to the human beings include ingestion of drinking water and consumption of foods and, to a lesser extent, inhalation of air.

\section{Materials and Methods}

\section{Study area}

Bhojpur district is situated in Bihar state and it is one of the thirty-eight districts of Bihar state and its administrative headquarter is located in Ara town. The total geographical area of Bhojpur district is $2395 \mathrm{~km} 2$. Bhojpur district falls within $25^{\circ} 10^{\prime \prime}$ to $25^{\circ} 40^{\prime \prime} \mathrm{N}$ and $83^{\circ} 45^{\prime}$ ', to $84^{\circ} 45^{\prime}$ ' E. The district area is bounded by the river Ganga in the north, Vindhyan hills in the south, the river Son in the east and Dharmawati-Gangi Rivers in the west. The urban and rural populations of the district are 2331450 and 388705 respectively, with total population around 2720155 (Census 2011). The district has three Sub Divisions namely Ara Sadar, Jagdishpur and Piro. The blocks of the district include Ara Sadar, Udwantnagar, Jagdishpur, Koilwar, Sahar, Barhara, Sandesh, Shahpur, Charpokhari, Piro, Tarari, Bihia, Agiawon and Garhani as shown in Figure 1.

\section{Climate and rainfall}

The study area has warm and humid climate.. The average temperature reaches $39^{\circ} \mathrm{C}$ during the months of April and May, whereas temperature decreases upto $6.3^{\circ} \mathrm{C}$ in the month of January. In the study area monsoon starts mostly from the mid of June and continues up to the end of the September. The normal annual rainfall of the district is 1080 $\mathrm{mm}$ which is calculated based on seventy years (1901- 1970) annual rainfall data (CGWB, 2013). The annual rainfall of the district varies from $1025 \mathrm{~mm}$ to $1106 \mathrm{~mm}$. About $85.46 \%$ of the total annual rainfall is obtained during monsoon period and the rest (only $14.54 \%$ approximately) occurs during the months of November to May (non monsoon season).

To measure the concentration of various water 
quality constituents of surface water or groundwater, specialized sampling and sample handling procedures are required. Total 45 water samples were collected from hand pumps and rivers during May, 2019 in, clean polypropylene bottles for trace metals analyses. The first few strokes of hand pump water were discarded to minimize the impact of stored waters. For analysis of trace metals, samples were acidified with conc. $\mathrm{HNO}_{3}$ at the rate of $2 \mathrm{ml} / \mathrm{L}$ of water samples.

The physical parameters such as $\mathrm{pH}$, electrical conductivity etc. was determined in the field using portable instruments (Hach, HQ30d portable meter). The water samples were brought to Roorkee and analyzed for various parameters in the laboratory of water quality lab, National Institute of Hydrology, Roorkee. The physico -chemical parameters were analyzed as per standard method (APHA, 2012;Jain and Bhatia, 1988).

The parameters analyzed to assess the water quality are $\mathrm{pH}$, Electrical conductivity (E.C), Turbidity, Total Dissolve Solids (TDS), Arsenic, Iron, Chromium, Nickel, Copper, Zinc, aluminum, Cadmium, Lead and Manganese.

The $\mathrm{pH}$ and electrical conductivity was measured by electrometric method and Arsenic and all other trace metals were analyzed by the instrument ICP OES.

\section{Trace metals}

Trace metals are elements such as $\mathrm{Co}, \mathrm{As}, \mathrm{Cr}$, $\mathrm{Fe}, \mathrm{Cu}, \mathrm{Mn}, \mathrm{Zn}$ and Se that generally occur at very low quantity in the environment. Living things need very small amounts of some trace metals, but high levels of these same metals can be toxic. For example, for many living things iron is an essential element, iron transports oxygen around the body in human blood.

\section{Principle of ICP OES}

The trace element analysis was conducted by ICP-OES (Inductively Coupled Plasma optical emission spectrometry). When plasma energy is given to an analysis sample from outside, the component elements (atoms) is excited. When the excited atoms return to low energy position, emission rays (spectrum rays) are released and the emission rays that correspond to the photon wavelength are measured. The element type is determined based on the position of the photon rays, and the content of each element is determined based on the rays' intensity.

To generate plasma, first, argon gas is supplied to torch coil, and high frequency electric current is applied to the work coil at the tip of the torch tube. Using the electromagnetic field created in the torch tube by the high frequency current, argon gas is ionized and plasma is generated. This plasma has high electron density and temperature $(10000 \mathrm{~K})$ and this energy is used in the excitation-emission of the sample. Solution samples are introduced into the plasma in an atomized state through the narrow tube in the center of the torch tube.

\section{Results and Discussion}

Total forty-five groundwater and river water samples were collected from the Bhojpur District, Bihar. The samples were analysed for trace metals for which analytical results of the chemical analysis are given in Table 1.

$\mathrm{pH}$ is one of the most important parameter in water chemistry and is defined as $\log \left[\mathrm{H}^{+}\right]$, and is measured as intensity of acidity or alkalinity on a scale ranging from $0-14$. In natural water, $\mathrm{pH}$ is governed by the equilibrium between carbon dioxide, bicarbonate and carbonates ions and in general, ranges between $\mathrm{pH} 4.5$ to 8.5. Although $\mathrm{pH}$ has no direct impact on the health of consumers, it is one of the most 
important operational water quality parameter. BIS (2012) has prescribed $\mathrm{pH}$ value in the range of 6.5 to 8.5 for for drinking water purpose. The $\mathrm{pH}$ of the water samples of study area varied from 6.9 to 8.5 with an average value of 7.57 (Table 1) and were well within the drinking water standards as prescribed by BIS (2012).

Electrical conductivity (EC) is a measure of the ability of an aqueous solution to carry an electric current. This ability depends on the presence of ions; on their total concentration, mobility, and valence; and on the temperature of measurement. The electrical conductivity and dissolved salt concentrations are directly related to the concentration of ionized substance in water and may also be related to problems of excessive hardness and/or other mineral contamination. In study area the electrical conductivity (EC) values varied from 277 to $1415 \mu \mathrm{Scm}^{-1}$ with an average value of $683 \mu \mathrm{Scm}^{-1}$ (Table 1) in groundwater.

Total Dissolved Solid (TDS) in water includes all dissolved material in solution, whether ionized or not. TDS is numerical sum of all mineral constituents dissolved in water and is expressed in $\mathrm{mg} / \mathrm{l}$.

TDS in drinking-water originates from natural sources, sewage, urban runoff and industrial wastewater. Concentrations of TDS in water vary considerably in different geological regions owing to differences in the solubility of minerals. BIS (2012) have prescribed 500 $\mathrm{mg} / \mathrm{l}$ as the acceptable limit and $2000 \mathrm{mg} / \mathrm{l}$ as permissible limit in absence of alternate source for drinking and other domestic usage. The total dissolved solids concentration in the all the analyzed water sample of the study area ranged from 177 to $905 \mathrm{mg} / \mathrm{l}$ with an average value of $437 \mathrm{mg} / \mathrm{l}$ given in (Table 1). The results show that in $48 \%$ of the sample TDS exceeded acceptable limit $(500 \mathrm{mg} / \mathrm{l})$ and none of the sample it exceeded the permissible limit of BIS (2012).

\section{Arsenic and other heavy metals distribution}

Heavy metals in ground water have a considerable significance due to their toxicity and adsorption behavior. Despite the presence of trace concentrations of $\mathrm{Cr}, \mathrm{Mn}, \mathrm{Co}, \mathrm{Cu}$ and $\mathrm{Zn}$ in the aquatic environment, which is essential to a number of life processes, high concentrations of these metals become toxic. The major sources of heavy metals in ground and surface water include weathering of rock minerals, discharge of sewage and other waste effluents on land and runoff water. The results of trace metal of the study area are given in the Table 1. The toxic effects of these elements and extent of their contamination in ground water is discussed in the following sections

\section{Arsenic (As)}

The results suggest that almost $40 \%$ of analysed samples fall within the acceptable limit of As (10 ppb) prescribed by BIS, 2012 (Fig. 2 and Fig. 3).

Approximately $\sim 60 \%$ of water samples collected from the study area were enriched with dissolved As concentrations $>10 \mu \mathrm{g} / \mathrm{L}$, and it ranged from below detectable limit (BDL) to $785 \mu \mathrm{g} / \mathrm{L}$ (average $162 \mu \mathrm{g} / \mathrm{L}$ ). Among the analysed samples about 11\% samples showed marginally elevated As (ranging between 10-50 $\mu \mathrm{g} / \mathrm{L}$ ) concentration in the Bhojpur area, whereas about 27 and 22 $\%$ of the analysed samples were in the range of $50-100 \mu \mathrm{g} / \mathrm{L}$ and above $100 \mu \mathrm{g} / \mathrm{L}$ respectively in the study area. In the present study, all the collected ground water samples were of shallow depth (Private hand pump/Tube wells, India Mark Hand pump: 30 to $160 \mathrm{ft}$ ).

Total As concentrations was extensively present in the ground water of study area along River Ganga as it can be observed from spatial distribution map of Arsenic (Fig. 4), 
which shows the location of two hotspot in the Bhojpur area. These regions are located along the Ganga river flood plains.

\section{Iron $(\mathrm{Fe})$}

The concentration of iron in the ground water of the study area ranged from 0.06 to 14.39 ppm with average concentration $2.81 \mathrm{ppm}$. The Bureau of Indian Standards has recommended $0.30 \mathrm{ppm}$ as the acceptable limit.

It is observed that $68.88 \%$ of the samples of the area exceeded the acceptable limit of 0.30 ppm. High concentration of iron may be attributed to the dissolution of iron bearing minerals from the soil strata. High concentrations of iron generally cause bitter and astringent taste to water.

The objection to iron in the distribution system is not due to health reason but for staining of laundry and plumbing fixtures and appearance.

\section{Manganese (Mn)}

The concentration of manganese ranges from 2.1 to $1303 \mathrm{ppb}$. A concentration of $100 \mathrm{ppb}$ has been recommended as a acceptable limit and $300 \mathrm{ppb}$ as the permissible limit for drinking water (BIS, 2012).

It is revealed from the results that about $15.55 \%$ of the analysed samples of the study area fall within the acceptable limit of 100 $\mathrm{ppb}$, and $35.35 \%$ samples exceeded the acceptable limit but were within the permissible limit of $300 \mathrm{ppb}$ whereas $64.65 \%$ of sample exceeded the permissible limit too.

\section{Aluminum (Al)}

The concentration of Aluminum in the ground water of the study area ranged from 35.1 to $1171 \mathrm{ppb}$ with an average of $124 \mathrm{ppb}$. The
Bureau of Indian Standards has recommended $30 \mathrm{ppb}$ as the acceptable limit and $200 \mathrm{ppb}$ as the permissible limit for drinking water (BIS, 2012).

It was evident from the results that $0.0 \%$ collected samples from the study area fell within the acceptable limit, $100 \%$ exceeded the acceptable limit and only $13.33 \%$ exceeded the permissible limit for drinking purpose.

\section{Copper (Cu)}

The concentration of copper ranged from BDL to $10 \mathrm{ppb}$, with an average value $4 \mathrm{ppb}$. The Bureau of Indian Standards has recommended $50 \mathrm{ppb}$ as the acceptable limit and $1500 \mathrm{ppb}$ as the permissible limit in the absence of alternate source (BIS, 2012).

In the study area, $100 \%$ of the samples fell well within the acceptable limit of $0.5 \mathrm{mg} / \mathrm{l}$ and none of the sample exceeded the permissible limit for drinking water.

\section{Lead $(\mathbf{P b})$}

In the study area, the concentration of lead ranged from BDL to $24 \mathrm{ppb}$. The Bureau of Indian Standards has prescribed $50 \mathrm{ppb}$ lead as the acceptable limit for drinking water (BIS, 2012). Beyond this limit, the water becomes toxic. In the study area, all samples fell well within the limit for drinking water.

\section{Chromium (Cr)}

The concentration of chromium was found below BDL to $5 \mathrm{ppb}$. A concentration of 50 ppb has been recommended as acceptable limit for drinking water (BIS, 2012).

In the study area, almost all the samples fell well within the acceptable limit for drinking water. 
Table.1 Distribution of As and other heavy metals concentration in the study area

\begin{tabular}{|c|c|c|c|c|c|c|c|c|c|c|c|c|c|c|}
\hline $\begin{array}{l}\text { Sample } \\
\text { Code }\end{array}$ & Location & pH & Ec & TDS & As ppb & Al ppb & $\begin{array}{c}\text { Cd } \\
\text { ppb }\end{array}$ & $\begin{array}{c}\mathrm{Cr} \\
\text { ppb }\end{array}$ & $\begin{array}{c}\mathrm{Cu} \\
\mathrm{ppb}\end{array}$ & $\begin{array}{c}\text { Ni } \\
\text { ppb }\end{array}$ & $\begin{array}{l}\mathrm{Pb} \\
\text { ppb }\end{array}$ & $\begin{array}{l}\text { Mn } \\
\text { ppb }\end{array}$ & $\begin{array}{c}\text { Zn } \\
\text { ppb }\end{array}$ & $\begin{array}{c}\text { Fe } \\
\text { ppm }\end{array}$ \\
\hline 1 & Paiga & 7 & 592 & 448 & 167 & 57 & ND & ND & 3 & ND & ND & 599 & 161 & 3.43 \\
\hline 2 & Paiga & 6.9 & 956 & 565 & 160 & 228 & ND & ND & 10 & $\mathrm{ND}$ & ND & 452 & 381 & 3.17 \\
\hline 3 & $\begin{array}{l}\text { Semaria } \\
\text { Ojhapati }\end{array}$ & 7 & 640 & 469 & 35 & 48 & ND & ND & 3 & ND & 12 & 322 & 150 & 1.3 \\
\hline 4 & $\begin{array}{l}\text { Semaria } \\
\text { Ojhapati }\end{array}$ & 7.1 & 567 & 460 & 7 & 51 & 1 & ND & 5 & ND & 5 & 348 & 848 & 0.67 \\
\hline 5 & $\begin{array}{l}\text { Semaria } \\
\text { Ojhapati }\end{array}$ & 7.1 & 636 & 475 & 105 & 46 & 1 & ND & 3 & ND & ND & 301 & 144 & 3.7 \\
\hline 6 & $\begin{array}{l}\text { Semaria } \\
\text { Ojhapati }\end{array}$ & 7.2 & 691 & 572 & 752 & 53 & 1 & ND & ND & ND & 6 & 390 & 212 & 6.17 \\
\hline 7 & $\begin{array}{l}\text { Semaria } \\
\text { Ojhapati }\end{array}$ & 7.2 & 598 & 529 & 10 & 50 & ND & ND & 4 & ND & 12 & 282 & 161 & 0.14 \\
\hline 8 & $\begin{array}{l}\text { Semaria } \\
\text { Ojhapati }\end{array}$ & 7.1 & 979 & 773 & 777 & 76 & 1 & ND & 4 & ND & ND & 636 & 147 & 14.39 \\
\hline 9 & $\begin{array}{l}\text { Semaria } \\
\text { Ojhapati }\end{array}$ & 7.6 & 498 & 469 & 8 & 53 & 1 & ND & 5 & ND & ND & 19 & 302 & 0.16 \\
\hline 10 & $\begin{array}{l}\text { Semaria } \\
\text { Ojhapati }\end{array}$ & 7.3 & 622 & 460 & 3 & 49 & ND & 2 & 2 & ND & 4 & 334 & 170 & 0.18 \\
\hline 11 & $\begin{array}{c}\text { Sahana } \\
\text { (Mangla) }\end{array}$ & 7.3 & 665 & 541 & 147 & 51 & 1 & ND & 3 & ND & 16 & 277 & 163 & 3.61 \\
\hline 12 & $\begin{array}{l}\text { Sudarpur } \\
\text { Barja }\end{array}$ & 7.3 & 470 & 419 & ND & 51 & ND & ND & 3 & ND & ND & 511 & 168 & 0.34 \\
\hline 13 & Balaharpur & 7.7 & 571 & 487 & ND & 36 & ND & ND & 4 & ND & ND & 357 & 182 & 0.3 \\
\hline 14 & Balaharpur & 7.5 & 456 & 376 & ND & 35 & ND & 2 & 4 & ND & ND & 346 & 167 & 0.06 \\
\hline 15 & $\begin{array}{l}\text { Barahara } \\
\text { (Ganga) }\end{array}$ & 8 & 540 & 456 & 74 & 332 & ND & ND & 3 & ND & ND & 158 & 202 & 0.58 \\
\hline 16 & Barahara & 7.6 & 541 & 487 & 95 & 47 & ND & ND & 7 & 7 & 24 & 126 & 1687 & 0.19 \\
\hline 17 & Sirsiyan & 7.2 & 772 & 606 & 785 & 57 & 1 & ND & ND & 2 & 10 & 745 & 245 & 13.6 \\
\hline 18 & Sirsiyan & 7.5 & 680 & 566 & 165 & 58 & ND & ND & 3 & ND & ND & 207 & 214 & 3.55 \\
\hline 19 & Hazipur & 7.8 & 383 & 342 & 30 & 302 & ND & ND & 7 & 11 & 8 & 909 & 288 & 4.31 \\
\hline 20 & Chamarpur & 7.2 & 732 & 646 & 338 & 53 & 1 & ND & 4 & ND & 8 & 624 & 196 & 5.53 \\
\hline 21 & Chamarpur & 7.9 & 801 & 680 & 104 & 54 & ND & ND & 3 & ND & 7 & 140 & 208 & 2.75 \\
\hline
\end{tabular}


Int.J.Curr.Microbiol.App.Sci (2019) 8(10): 1421-1431

\begin{tabular}{|c|c|c|c|c|c|c|c|c|c|c|c|c|c|c|}
\hline 22 & Sirhiya & 7.4 & 692 & 490 & ND & 54 & ND & ND & 2 & ND & ND & 569 & 209 & 0.2 \\
\hline 23 & Sirhiya & 7.5 & 724 & 600 & 40 & 83 & 1 & 2 & 6 & ND & 12 & 525 & 2190 & 1.72 \\
\hline 24 & Sirsiya & 7.5 & 560 & 415 & ND & 60 & 3 & ND & 5 & ND & 6 & 490 & 143 & 0.2 \\
\hline 25 & Ishwarpura & 7.5 & 1050 & 1034 & 360 & 60 & 1 & ND & 4 & ND & ND & 330 & 183 & 0.3 \\
\hline 26 & Ishwarpura & 7.9 & 629 & 469 & 106 & 49 & 1 & ND & 0 & ND & 9 & 127 & 154 & 1.28 \\
\hline 27 & Ishwarpura & 7.7 & 810 & 768 & 346 & 58 & 1 & ND & 4 & ND & 6 & 503 & 201 & 6.81 \\
\hline 28 & Ishwarpura & 7.5 & 925 & 740 & 659 & 69 & 1 & ND & 3 & ND & ND & 587 & 167 & 8.25 \\
\hline 29 & Ishwarpura & 7.1 & 1415 & 897 & 497 & 75 & 1 & ND & 2 & ND & 12 & 626 & 382 & 13.65 \\
\hline 30 & Ishwarpura & 8.1 & 964 & 725 & 765 & 122 & 1 & ND & 2 & ND & 8 & 782 & 199 & 3.1 \\
\hline 31 & Baligaon & 7.5 & 522 & 463 & 6 & 48 & ND & ND & 5 & ND & 12 & 470 & 151 & 0.11 \\
\hline 32 & Naika Tola & 7.7 & 405 & 360 & ND & 37 & 1 & ND & 3 & 3 & 9 & 89 & 140 & 0.23 \\
\hline 33 & Jaithwar & 7.5 & 850 & 594 & ND & 80 & ND & 5 & 3 & ND & ND & 4 & 138 & 0.12 \\
\hline 34 & Bahnuwa & 7.4 & 629 & 497 & ND & 58 & ND & 2 & 2 & ND & 8 & 8 & 174 & 0.23 \\
\hline 35 & Anhari & 8.3 & 277 & 237 & ND & 577 & ND & ND & 5 & ND & ND & 37 & 169 & 0.75 \\
\hline 36 & Anhari & 8 & 482 & 379 & ND & 39 & 1 & 2 & 3 & ND & 13 & 4 & 116 & 0.15 \\
\hline 37 & Sahar & 8.2 & 815 & 623 & 12 & 64 & 83 & 5 & 4 & ND & ND & 2 & 154 & 0.1 \\
\hline 38 & Bhagwanpur & 8.1 & 942 & 403 & 5 & 47 & ND & ND & 2 & 4 & 15 & 306 & 128 & 0.12 \\
\hline 39 & Bibiganj & 7.9 & 592 & 402 & 139 & 43 & 1 & ND & ND & 4 & 5 & 380 & 110 & 1.78 \\
\hline 40 & Maulighat & 8.5 & 526 & 381 & 17 & 1171 & 1 & 1 & 6 & ND & ND & 132 & 141 & 1.76 \\
\hline 41 & Maulighat & 7.6 & 1033 & 828 & ND & 70 & 1 & ND & 1 & ND & ND & 1303 & 163 & 0.11 \\
\hline 42 & Mauzampur & 7.7 & 815 & 709 & 138 & 62 & 1 & ND & 6 & ND & 12 & 324 & 1631 & 4.36 \\
\hline 43 & Bindgaon & 8.2 & 380 & 267 & ND & 732 & ND & ND & 6 & 2 & ND & 111 & 155 & 1.15 \\
\hline 44 & Bindgaon & 7.7 & 732 & 593 & 252 & 59 & 1 & ND & 2 & ND & ND & 549 & 129 & 3.53 \\
\hline 45 & Manikpur & 7.9 & 584 & 495 & 193 & 68 & 1 & ND & 3 & ND & ND & 1221 & 250 & 6.96 \\
\hline Minimum & & 6.9 & 277 & 237 & ND & 35.1 & ND & ND & ND & ND & ND & 2.1 & 110 & 0.06 \\
\hline Maximum & & 8.5 & 1415 & 1034 & 785 & 83 & 5 & 10 & 11 & 24 & 1303 & 2190 & 14.39 & 14.39 \\
\hline Average & & 7.6 & 683 & 538 & 162 & 2 & 0 & 4 & 1 & 5 & 390 & 310 & 2.81 & 2.81 \\
\hline
\end{tabular}


Fig.1 Study Area of Bhojpur district

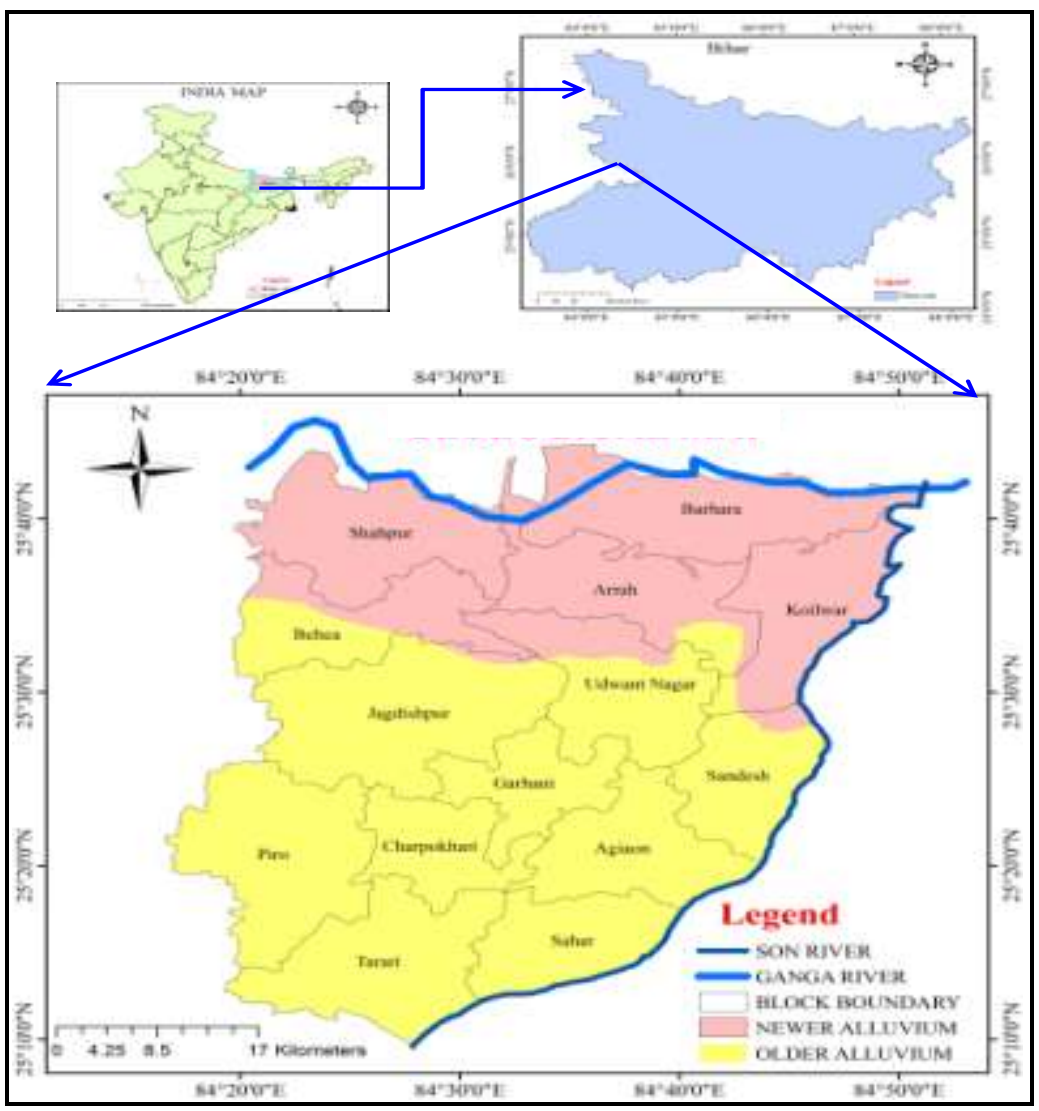

Fig.2 Sampling Location of Study Area

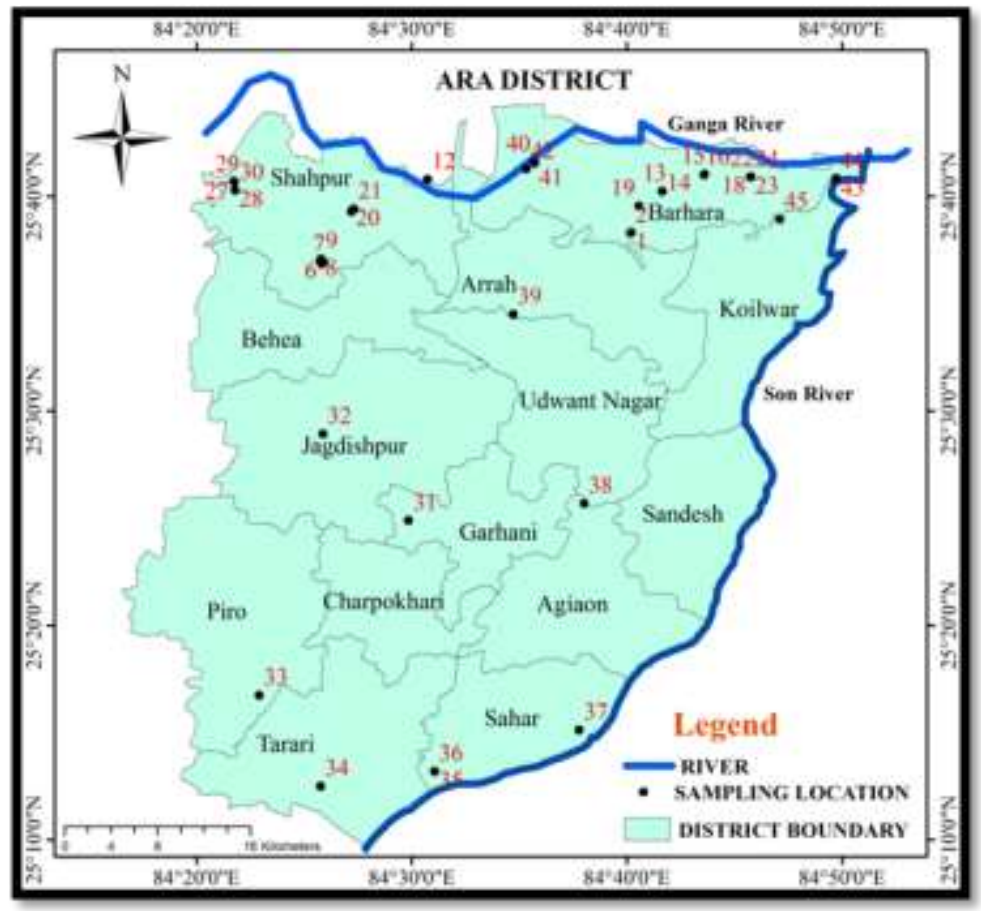


Fig.3 Arsenic affected sample in (\%) of Bhojpur district

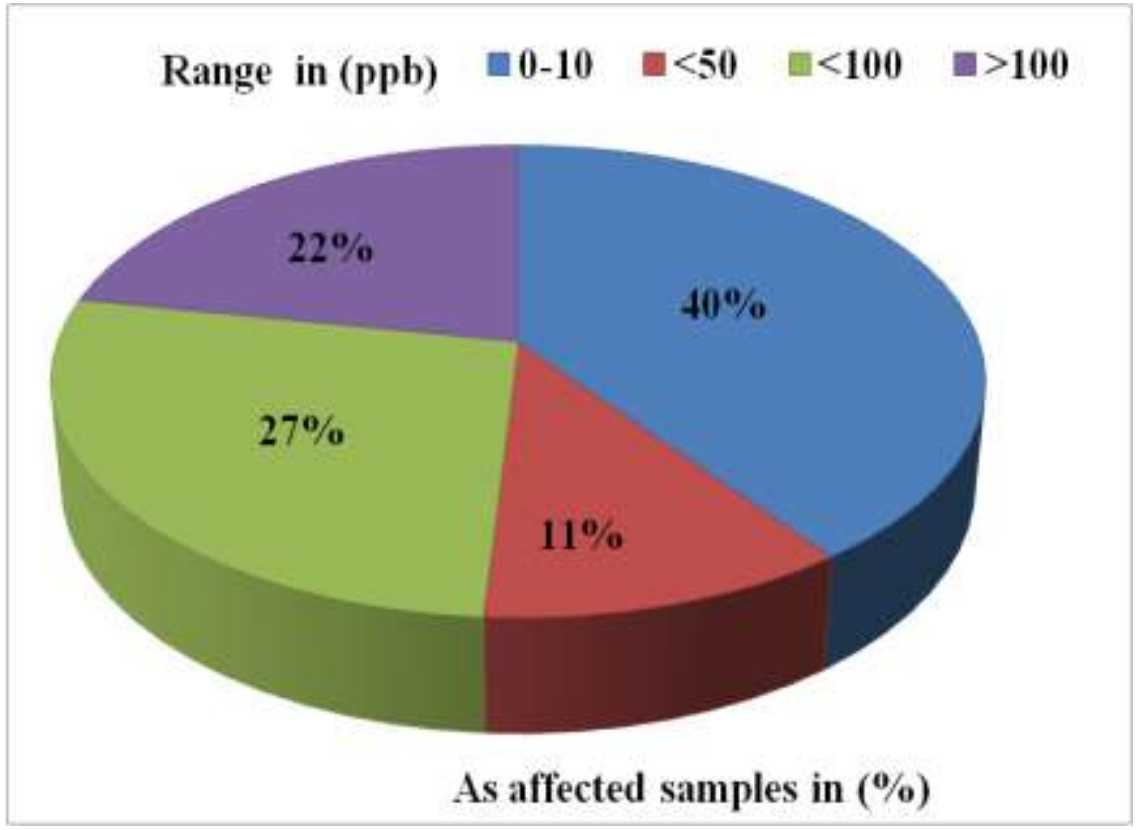

Fig.4 As distribution map of the study area

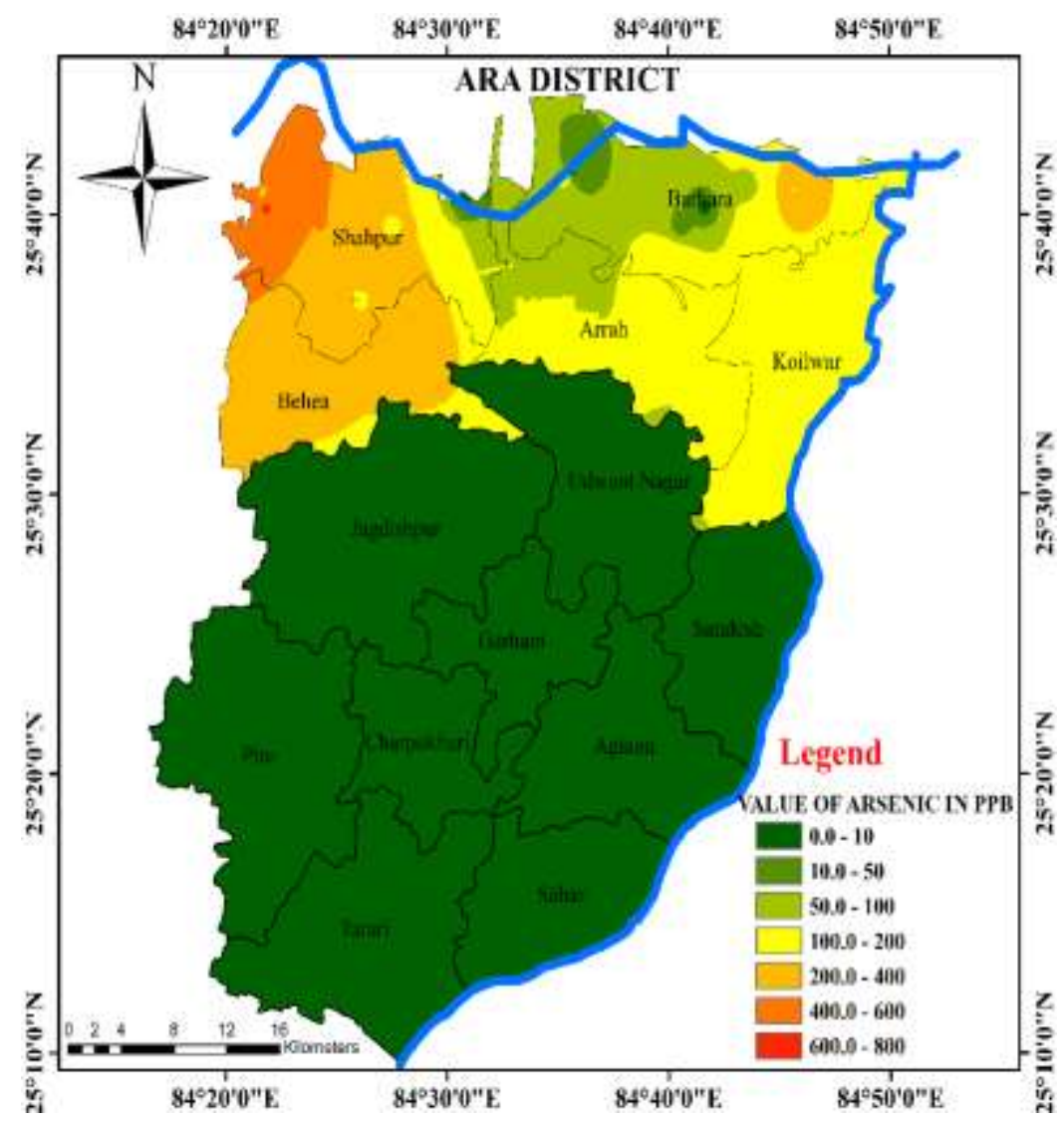




\section{Cadmium (Cd)}

Cadmium is a non essential non-beneficial element known to have a high toxic potential. The cadmium content in the study area varied from BDL to $83 \mathrm{ppb}$ during the study period. The Bureau of Indian Standards has prescribed $3 \mathrm{ppb}$ cadmium as the acceptable limit for drinking water (BIS, 2012). Beyond this limit, the water becomes toxic. In the study area, only $4.44 \%$ samples fell beyond the acceptable limit during this sampling period.

\section{Nickel (Ni)}

The concentration of Nickel in the ground water of the study area ranged from BDL to $11 \mathrm{ppb}$. The Bureau of Indian Standards has recommended $30 \mathrm{ppb}$ as the permissible limit for drinking water (BIS, 2012). It was evident from the results that nickel concentration in all the groundwater samples fell well within the permissible limit.

\section{Zinc (Zn)}

The concentration of zinc in the study area ranged from $110 \mathrm{ppb}$ to $2190 \mathrm{ppb}$. The Bureau of Indian Standards has prescribed $5000 \mathrm{ppb}$ zinc as the acceptable limit and $15000 \mathrm{ppb}$ as the permissible limit for drinking water (BIS, 2012). In the study area, 100 percent of total analysed samples were found under the acceptable limit.

The deterioration of ground water quality due to geogenic and anthropogenic activities causes the concern for policy makers. The quality of ground water has undergone a change to an extent that the use of such water could be hazardous. Ground water contamination with arsenic (As) is one of the major threats to human health. In India, high concentration of arsenic beyond permissible limit of $0.05 \mathrm{mg} / \mathrm{l}$ in ground water has been reported from 86 districts of 10 States.
States like West Bengal, Bihar, Uttar Pradesh, Assam, Madhya Pradesh and parts of Chandigarh are facing acute problem of arsenic contamination. The ground water of Bhojpur district, Bihar has been reported to be severely contaminated with arsenic. In the present study, forty five water samples were collected from all the blocks, mainly focussing on four blocks namely Shahpur, Barhara, Ara and Koilwar of Bhojpur district, Bihar. The Arsenic and Iron has been found in the range $(0-785 \mathrm{ppb})$ and (0.06-14.39 $\mathrm{mg} / \mathrm{L})$ respectively in the study area. The enrichment of As was encountered in the sampling sites that were close to the flood plain of Ganges river. For better drinking management policy, government and other water supply and investigation department may target continuous monitoring of the arsenic affected area and a detailed hydro-geochemical and arsenic genesis study should be carried out for better understanding of arsenic occurrence.

\section{References}

APHA (2012). Standard methods for the examination of water \& wastewaters, American public health association, $22^{\text {th }}$ edition, Washington dc.

Bhattacharya, P., Tandulkar N., and Neku A.. 2003. Geogenic arsenic in groundwater from Terai alluvial plain of Nepal. Journal of Physics IV France 107:173176.

BIS (2001), Indian Standard - Guidelines for the quality of Irrigation water, IS 11624:1986, Bureau of Indian Standards, New Delhi.

Biswas, B. K., Inoue J., Inoue K. 2008. Adsorptive removal of $\mathrm{As}(\mathrm{V})$ and As(III) from water by a Zr(IV)- loaded orange waste gel. Journal of Hazardous Materials 154:1066-1074.

CGWB 2013. Groundwater information booklet of Bhojpur district, Bihar. Central Groundwater Board, Ministry 
of Water Resources, RD \& GR. Government of India.

CGWB 2018. Groundwater quality in shallow aquifers in India. Central Groundwater Board, Ministry of Water Resources, RD \& GR. Government of India.

Chakraborti, D., Rahman M. M., and Alauddin M. 2015. Groundwater arsenic contamination in Bangladesh - 21 years of research. Journal of Trace Elements in Medicine and Biology 31:237-248.

Das B., Rahman M. M., and Nayak B. 2009. Groundwater arsenic contamination, its health effects and approach for mitigation in West Bengal, India and Bangladesh. Water Quality, Exposure and Health 1:5-21.

Fendorf, S., Michael H. A., and van Geen A. 2010. Spatial and temporal variations of groundwater arsenic in South and Southeast Asia. Science 328(5982):1123-1127.

Hassan, M. M. 2018. Arsenic in Groundwater: Poisoning And Risk Assessment. Crc Press.

Mirlean, N., Baisch P., and Diniz D. 2014. Arsenic in groundwater of the Paraiba do Sul delta, Brazil: An atmospheric source? Science of the Total Environment 482-483:148-156.

Nguyen, V. A., Bang S., and Viet P. H. 2009. Contamination of groundwater and risk assessment for arsenic exposure in $\mathrm{Ha}$ Nam province, Vietnam. Environment International 35:466-472.

Shankar, S., Shanker U., and Shikha. 2014. Arsenic contamination of groundwater: A review of sources, prevalence, health risks, and strategies for mitigation. The Scientific World Journal 2014:1-18. [http://dx.doi. org/10.1155/2014/304524].

Shi, H., Shi X., and Liu K. J. 2004. Oxidative mechanism of arsenic toxicity and carcinogenesis. Molecular and Cellular Biochemistry 255(1-2):67-78.

Smedley, P. L. and Kinniburgh D. G.2002. A review of the source, behaviour and distribution of arsenic in natural waters. Applied Geochemistry 17(5):517-568.

Smith, A. H., Lingas E.O, and Rahman. M. 2000a. Contamination of drinkingwater by arsenic in Bangladesh: A public health emergency. Bulletin of the World Health Organization 78:1093-1103.

Violante, A., Ricciardella, M., and Gaudio S.D.2006. Coprecipitation of arsenate with metal oxides: nature, mineralogy, and reactivity of aluminum precipitates. Environmental Science and Technology. 40:4961-4967.

\section{How to cite this article:}

Manish Kumar, V. K. Chandola and Sumant Kumar. 2019. Groundwater Arsenic Contamination and its Distribution in Bhojpur District, Bihar, India. Int.J.Curr.Microbiol.App.Sci. 8(10): 1421-1431. doi: https://doi.org/10.20546/ijcmas.2019.810.167 